\title{
POTENTIAL USE OF ORGANIC MINERAL AS MINERAL SOURCE FOR DIET OF JUVENILE VANNAMEI SHRIMP, Penaeus vannamei
}

\author{
Asda Laining", Rachman Syah, and Muslimin \\ Research and Development Institute for Coastal Aquaculture
}

(Received 12 May 2014; Final revised 25 May 2015; Accepted 8 June 2015)

\begin{abstract}
The use of organic mineral $(\mathrm{OM})$ has been recently introduced in aquaculture both as feed supplement and water quality improvement. A feeding experiment was conducted to evaluate a response dose of OM on growth, survival, and mineral content in whole the body and carapace of vannamei shrimp (Penaeus vannamei). Three diets were supplemented with different levels of organic mineral at 1 (OM1), 2 (OM2) and 4 (OM4) g/ $100 \mathrm{~g}$ diet. Positive control was a diet without OM inclusion but supplemented with commercial mineral mixture at level of $4 \mathrm{~g} / 100 \mathrm{~g}$ diet. Juvenile vannamei shrimp with average initial body weight of $3.5 \pm 0.1 \mathrm{~g}$ were stocked into 12 tanks with a capacity of $200 \mathrm{~L}$. After 75 days feeding trial, highly significant weight gains was observed in shrimp fed OM at all levels compared to the positive control. However, no significant differences were found among dietary OM groups. The growth response was clearly shown by the same values of SGRs in the three OM supplemented groups $(1.1 \% / \mathrm{d})$ and only differed significantly from positive control. Increasing of dietary OM significantly improved survival rate of shrimp where the highest was observed in group fed OM1 and the lowest was in control diet. Effect of dietary OM on whole body Ca and $\mathrm{P}$ were quite similar while whole body $\mathrm{Ca}$ and $\mathrm{P}$ content of OM1 group was slightly high and tended to decrease in two groups with higher level dietary OM. However, no significant differences among the treatment groups. A clear response of supplementing OM in diet was detected on whole body $\mathrm{Zn}$ content. Increase of dietary OM resulted in an increase of $\mathrm{Zn}$ content in whole body. The effect was clearly shown when diet contained $2 \%$ and $4 \%$ OM. Carapace Ca content was highly significant when diet contained $2 \%$ $\mathrm{OM}$. Similar to whole body $\mathrm{Zn}$ content, there was also a linear trend of response dose of dietary OM on carapace $\mathrm{Zn}$ content which the highest was found in dietary OM4. Based on growth, survival rate, and $\mathrm{Zn}$ content in whole body and carapace, dietary $\mathrm{OM}$ at $1 \mathrm{~g} / 100 \mathrm{~g}$ diet can replace mineral mixture as mineral source in diet of vannamei shrimp.
\end{abstract}

KEYWORDS: organic mineral, carapace mineral, growth, vannamei shrimp

\section{INTRODUCTION}

Fish, unlike most terrestrial animals have the ability to absorb some inorganic element not only from diet but also from their environment in both freshwater and seawater. Fish require mineral for skeletal formation, maintenance of colloidal systems (osmotic pressure, viscosity, diffusion), regulation of acid-base equilibrium, and for biologically important compound such hormones and enzymes and activators of enzymes (Lall, 2002).

Fish require mineral only in very small amount, however they are absolutely required for normal growth. Fish fulfill their mineral requirement through

\# Corresponding: Research and Development Institute for Coastal Aquaculture. Jl. Makmur Dg. Sitakka No. 129, Maros 90512, South Sulawesi, Indonesia. Tel.: + (0411) $371544 / 5$ E-mail: asdalaining@yahoo.com diet or absorb from water depending on bioavailability of the mineral-element. Several factors influenced bioavailability of element include dose and form of mineral sources, particle size and digestibility of diet, interaction between nutrient which may be either synergetic or antagonistic, physiological, and pathological condition of the fish, and mineral concentration in the water (Watanabe et al., 1997; Lall, 2002; Laining et al., 2011).

Essential mineral such as calcium, phosphorus, potassium, sodium, iron, copper, zinc, cobalt, selenium, and magnesium are usually included in mineral or vitamin premixes and together with other ingredients are mixed to make artificial diet. Most of mineral premix supplemented in diet is in the form of inorganic. Commercial mineral premix used by feed companies is mostly imported from other countries like other major ingredients used for aquafeed (Laining 
\& Kristanto, 2015). As imported ingredients, the price of mineral mixtures tends to increase by years. In addition, even though mineral mixture is supplemented in the diet only at low level $(1 \%-4 \%)$, its price is considered as expensive material in particular those used for shrimp diet (150,000-350,000 IDR per kg).

To date, organic mineral (OM) has been introduced to use as supplement for shrimp and fish diet. Texture of OM tested in this experiment is a fined powder produced from lava of Krakatau volcano combined with natural mines. It mainly contains supra bio-molecular, amino acid, carbohydrates, macro and micro mineral as well as trace mineral. In order to find alternative mineral sources for shrimp diet, a feeding trial was conducted to evaluate a response dose of OM supplementation on growth, survival, and mineral utilization of vannamei shrimp.

\section{MATERIALS AND METHODS}

\section{Feed Ingredients and Experimental Diets}

Basal diets were formulated using full-fat soybean and soybean cake meal supplemented with methionine as the major protein sources. Soybean cake is by-product of tofu processing which is called ampas tahu in Bahasa. A graded level of OM was incorporated at $1 \%, 2 \%$, and $4 \%$ in diet. A control group without OM supplementation was included with commercial mineral mixture (inorganic form) at level of $4 \%$ constituting a total of four dietary treatments. For- mulation of each diet was presented in Table 1. Diets were formulated to be iso-nitrogenous as shown in Table 2.

All diets were prepared by mixing thoroughly of dry ingredients followed by oil containing oil-soluble micro-ingredients/vitamin. The mixture was then added with an adequate amount of distilled water around $30 \%-35 \%$ and then passed through a pelletizer (Hiraga, Kobe, Japan). After drying, diets were steamed for around $2 \mathrm{~min}$. and stored at $-20^{\circ} \mathrm{C}$ until used.

\section{Experimental Shrimp and Rearing Conditions}

Post-larvae vannamei shrimp were obtained from commercial hatchery in Barru Regency and transferred to laboratory for nursing around two weeks in concrete tank. Juvenile vannamei shrimp were selected and distributed into 12 fiber tanks with a capacity of $200 \mathrm{~L}$. Average body weight of shrimp used in the trial was $3.5 \pm 0.1 \mathrm{~g}( \pm \mathrm{STD})$. Each tank was provided with aeration to maintain dissolved oxygen levels at near saturation. Water was exchanged every day in the morning after cleaning the feces and uneaten diet. Water temperature ranged from $24.1^{\circ} \mathrm{C}$ to $28.9^{\circ} \mathrm{C}, \mathrm{pH}$ from 7.9 to 8.1 ; dissolved oxygen from 5.3 to 7.6 $\mathrm{mg} / \mathrm{L}$ and salinity from 34 to $35 \mathrm{ppt}$.

Each experimental diet was fed to the three replicates groups of vannamei shrimp for 75 days. Treatment groups were fed their respective diets at a rate

Table 1. Formulation of experimental diets (g/100 g diet)

\begin{tabular}{lcccc}
\hline \multirow{1}{*}{ Ingredients } & \multicolumn{4}{c}{ OM dosages } \\
\cline { 2 - 5 } & Positive control & OM1 & OM2 & OM4 \\
\hline Local fishmeal & 15 & 15 & 15 & 15 \\
Mysid meal & 14 & 14 & 14 & 14 \\
Full-fat soybean meal & 20 & 20 & 20 & 20 \\
Soybean cake meal & 20 & 20 & 20 & 20 \\
Peas meal & 5 & 5 & 5 & 5 \\
Wheat gluten & 6 & 6 & 6 & 6 \\
Rice bran & 8 & 8 & 8 & 8 \\
Fish oil & 2 & 2 & 2 & 2 \\
Soybean oil & 1 & 1 & 1 & 1 \\
Lecithin & 1 & 1 & 1 & 1 \\
Cholesterol & 0.5 & 0.5 & 0.5 & 0.5 \\
Methionine & 0.2 & 0.2 & 0.2 & 0.2 \\
Vitamin mix & 2 & 2 & 2 & 2 \\
Stay-C & 0.5 & 0.5 & 0.5 & 0.5 \\
Commercial mineral mixture & 4 & 0 & 0 & 0 \\
Commercial organic mineral & 0 & 1 & 2 & 4 \\
Cellulose & 0.8 & 3.8 & 2.8 & 0.8 \\
\hline
\end{tabular}


Table 2. Chemical composition of experimental diets ( $\mathrm{g} / 100 \mathrm{~g}$ diet)

\begin{tabular}{lcccc}
\hline \multirow{2}{*}{ Nutrients } & \multicolumn{4}{c}{ OM dosages } \\
\cline { 2 - 5 } & Positive control & OM1 & OM2 & OM4 \\
\hline Moisture & 8.4 & 9.2 & 9.3 & 8.8 \\
Crude protein & 34.8 & 32.8 & 33.2 & 33.7 \\
Total lipid & 12.8 & 12.1 & 12.8 & 13.3 \\
Ash & 11.8 & 10.3 & 11.6 & 9.7 \\
\hline
\end{tabular}

of $5 \%$ body weight per day, given twice a day in the morning and afternoon. Uneaten feeds were collected daily before morning feeding. Growth and feeding consumption were monitored every 15 days by collectively weighing each group and the daily feed allocation was adjusted accordingly.

\section{Sample Collection and Biochemical Analysis}

At the end of the feeding trial, shrimp were bulk weighed from each tank and taken 5-10 shrimps, dried, blended and then stored at $-20^{\circ} \mathrm{C}$ until analysis. Carapace of another 5-10 shrimps were removed from the body, clean of connective tissues and washed with distilled water. The carapaces were finally defatted with extraction of chloroform/methanol (2:1) according to Folch et al. (1958). Defatted carapaces were dried, pulverized with mortar and pestle and stored at $-20^{\circ} \mathrm{C}$ until mineral analysis. After removing carapaces, muscle was taken, dried, blended, and stored at $-20^{\circ} \mathrm{C}$.

Proximate analysis of the diet and protein content of carcass and muscle were analyzed according to AOAC (1999). Mineral content of tested minerals, carcass and carapace were determined with atomic absorption spectrophotometer (ASS, Shimadzu, Tokyo, Japan) except for phosphorus content which was measured spectro-photometrically after acid diges- tion. Amino acid analysis was carried out using HPLC (Shimadzu 20A, Tokyo, Japan).

\section{Calculation and Statistical Analysis}

Biological parameters were calculated including weight gain (WG), specific growth rate (SGR), and survival rate (SR). Data on the growth performances and mineral content in the carcass and carapace among the treatment group were analyzed by one-way analysis of variance (ANOVA) $(\mathrm{P}<0.05)$ and Tukey's honest significant difference test (SPPS version 17).

\section{RESULTS AND DISCUSSIONS}

\section{Nutrient Content of Organic Mineral}

Mineral content of OM and commercial mineral mixture used in test diet are shown in Table 3. Concentrations of macro and micro minerals analyzed in commercial mineral mixture (in-organic form) were generally higher than that of $\mathrm{OM}$, except for $\mathrm{K}, \mathrm{Al}$, and $\mathrm{Na}$. According to the product specification, the $\mathrm{OM}$ is claimed to contain 21 amino acid and 17 fraction of carbohydrate. In addition, mineral contained in the product includes 5 macro-mineral namely $\mathrm{Ca}$, $\mathrm{Mg}, \mathrm{Ba}, \mathrm{K}$, and $\mathrm{Na}$ and 67 elements of micro and trace mineral. As organic material, the product also contains carbon, hydrogen, oxygen, nitrogen, sulphur, and phosphorus.

Table 3. Mineral composition of commercial mineral mixture and organic mineral supplemented in tested diet

\begin{tabular}{lcc}
\hline \multicolumn{1}{c}{ Mineral } & $\begin{array}{c}\text { Commercial mineral mix } \\
(\mathbf{m g} / \mathbf{k g})\end{array}$ & $\begin{array}{c}\text { Organic mineral } \\
(\mathbf{m g} / \mathbf{k g})\end{array}$ \\
\hline Phosphorus (P) & 400 & 91.97 \\
Calcium (Ca) & 30,000 & 667.78 \\
Magnesium (Mg) & 8,600 & 674.70 \\
Aluminium (Al) & 700 & $4,958.14$ \\
Potassium (K) & 300 & $7,863.80$ \\
Mangan (Mn) & 650 & 104.36 \\
Sodium (Na) & 190 & $1,245.24$ \\
Nickel (Ni) & 90 & $<0.05$ \\
Zinc (Zn) & 830 & 81.06 \\
\hline
\end{tabular}


As shown in Table 4, the OM contained 8.9 g protein $/ \mathrm{kg}(8,900 \mathrm{mg} / \mathrm{kg})$ and several essential amino acids were also detected. Similar analysis was not carried out on commercial mineral mixture which was an inorganic form containing negligible protein.

\section{Effects on Growth and Survival Rate}

Growth response and survival rate after 75 days feeding trial are presented in Table 5 . Highly significant WGs in shrimp fed OM were observed in all levels of OM compared to control diet. WG tended to increase with increasing the level of OM in diet, but no significant differences among OM supplemented groups. This was clearly shown by the same values of SGRs in the three OM supplemented groups $(1.1 \% / d)$ and only differed significantly from positive control.

Clear effect of OM supplemented diet was observed in SR of the shrimp. SR increased by inclusion of OM in diets and the highest SR was found in shrimp fed OM1 and the lowest SR occured in control diet.

Inclusion of $1 \% \mathrm{OM}$ in diet had better effect on growth and SR than 4\% inorganic mineral (mineral mixture). Althogh determination of the mineral content of the mineral sources used in this experiment was carried-out only for certain elements (Table 3), it is suspected that trace mineral such as selenium (Se), and mangan (Mn) contained in OM may contribute to

Table 4. Crude protein and amino acid profiles of organic mineral tested in the experiment $(\mathrm{n}=2)$

\begin{tabular}{lc}
\hline \multicolumn{1}{c}{ Nutrient } & $\mathrm{mg} / \mathrm{kg}$ \\
\hline Crude protein & $8,900 \pm 49.97$ \\
\hline Amino acid profiles: & \\
Aspartic acid & $54.30 \pm 0.14$ \\
Glutamin acid & $69.62 \pm 1.15$ \\
Serine & $92.16 \pm 0.25$ \\
Histidine & $23.08 \pm 0.74$ \\
Glycine & $76.42 \pm 1.33$ \\
Threonine & $27.28 \pm 0.77$ \\
Arginine & $26.55 \pm 0.25$ \\
Alanine & $51.91 \pm 0.16$ \\
Tyrosine & $24.52 \pm 0.12$ \\
Methionine & $19.11 \pm 0.30$ \\
Valine & $43.48 \pm 0.21$ \\
Phenylalanine & $95.11 \pm 0.05$ \\
Isoleucine & $125.44 \pm 0.25$ \\
Leucine & $280.14 \pm 0.42$ \\
Lysine & $306.75 \pm 0.08$ \\
\hline
\end{tabular}

Note: Values are the mean $\pm \mathrm{SD}$ the higher growth and survival rate of the shrimp compared to control group. Se is a component of the enzyme glutathione peroxidase which catalyzes reactions necessary for the conversion of hydrogen peroxide and fatty acid hydroperoxides into water and fatty acid alcohol by using reduced glutathione, thereby protecting cell membranes against oxidative damage (Rotruck et al., 1973). Commercial mineral mixture used as control in this study may also contain Se, but vannamei shrimp might utilize Se from $\mathrm{OM}$ better than in form of inorganic. Organic Se (selenomethionine) has been reported to have higher bioavailability than the inorganic Se (sodium selenite) for juvenile grouper, Epinephelus malabaricus (Lin \& Shiau, 2005), Atlantic salmon (Lorentzen et al., 1994), and channel catfish (Wang \& Lovell, 1997). However, inclusion level of OM at low dosage seemed sufficient for a better growth of vannamei shrimp, indicated by a steady growth and SR of the shrimp at a higher levels of OM supplementation.

Growth response of vannamei shrimp found in this trial is difficult to compare with other aquatic animal since similar studies are very rare available. Fodge et al. (2011) reported that juvenile tilapia $(1 \mathrm{~g})$ had the best performance when it was given $0.5 \%$ organic mineral (commercial name: Azomite) with the highest WG and a $16.5 \%$ improvement in FCR from 1.55 to 1.33 . Similar trial was carried out on the bigger size of tilapia $(20 \mathrm{~g})$ also produced significant improvement of growth over the control and inclusion rate of 0.25 to 0.75 gave the same effect. A possible mode of action of the organic mineral was a significant increase of pepsin and pancreatic protease in the stomach and small intestine of the tilapia with the presence of the organic mineral in diet (Fodge et al., 2011). It is well known that the synthesis of enzymes requires a wide range of trace minerals for optimization. The key digestive enzymes in the gut are boosted allowing the fish to digest the feed more completely, lowering FCR, and increasing the WG. Even though digestive enzymes were not analyzed in this experiment, it is suspected that similar evidence may also happen in vannamei shrimp by feeding the organic mineral.

\section{Protein and Mineral Content in Whole Body and Carapace}

Protein content in whole body and muscle is presented in Table 6 . Whole body or carcass protein content was slightly lower than in muscle. Range of protein content in whole body vannamei shrimp was from $64 \%$ to $67 \%$ while in muscle was from $70 \%$ to $72 \%$. Moreover, dose of OM tested in this experiment did not have a significant effect on both whole body and muscle protein content. 
Table 5. Growth performances and survival rate of vannamei shrimp after 75 days fed a graded level of organic mineral

\begin{tabular}{lcccc}
\hline \multirow{2}{*}{ Parameter } & \multicolumn{4}{c}{ OM dosages } \\
\cline { 2 - 5 } & Positive control & OM1 & OM2 & OM4 \\
\hline Initial weight $(\mathrm{g})$ & $3.4^{\mathrm{a}} \pm 0.0$ & $3.4^{\mathrm{a}} \pm 0.0$ & $3.5^{\mathrm{a}} \pm 0.0$ & $3.5^{\mathrm{a}} \pm 0.0$ \\
Final weight $(\mathrm{g})$ & $6.0^{\mathrm{a}} \pm 1.4$ & $7.7^{\mathrm{b}} \pm 0.3$ & $7.9^{\mathrm{b}} \pm 0.5$ & $7.9^{\mathrm{a}} \pm 0.8$ \\
Weight gain $(\%)$ & $75.9^{\mathrm{a}} \pm 28.7$ & $127.7^{\mathrm{b}} \pm 13.1$ & $128.0^{\mathrm{b}} \pm 15.6$ & $129.9^{\mathrm{b}} \pm 15.1$ \\
Specific growth rate $(\% / \mathrm{d})$ & $0.8^{\mathrm{a}} \pm 0.2$ & $1.1 \mathrm{~b} \pm 0.1$ & $1.1^{\mathrm{b}} \pm 0.1$ & $1.1^{\mathrm{b}} \pm 0.1$ \\
Survival rate $(\%)$ & $59.8^{\mathrm{a}} \pm 6.5$ & $89.0^{\mathrm{c}} \pm 1.0$ & $72.0^{\mathrm{ab}} \pm 13.1$ & $77.0^{\mathrm{bc}} \pm 1.0$ \\
\hline
\end{tabular}

Note: Values are the mean \pm SD . The mean values with different superscript are significantly different $(\mathrm{P}<0.05)$

Table 6. Protein content (\%) of whole body and muscle of vannamei shrimp fed a graded levels of organic mineral $(\mathrm{n}=3)$

\begin{tabular}{lcccc}
\hline \multirow{2}{*}{ Parameter } & \multicolumn{4}{c}{ OM dosages } \\
\cline { 2 - 5 } & Positive control & OM1 & OM2 & OM4 \\
\hline Whole body protein & $64.5^{\mathrm{a}} \pm 0.5$ & $64.6^{\mathrm{a}} \pm 6.2$ & $66.7^{\mathrm{a}} \pm 1.1$ & $67.0^{\mathrm{a}} \pm 0.9$ \\
Muscle protein & $70.3^{\mathrm{a}} \pm 1.8$ & $72.3^{\mathrm{a}} \pm 5.4$ & $71.1^{\mathrm{a}} \pm 1.3$ & $70.3^{\mathrm{a}} \pm 0.6$ \\
\hline
\end{tabular}

Note: Values are the mean \pm SD . The mean values with different superscript are significantly different $(\mathrm{P}<0.05)$

Concentration of mineral in whole body and carapace is shown in Table 7 . Whole body Ca was higher in shrimp fed OM1 than other three groups and tended to decrease in two groups contained higher level dietary OM. However, no significant differences among the treatment groups. Similar trend was found in whole body $\mathrm{P}$ that dietary OM did not significantly affect $\mathrm{P}$ content in whole body. However, there was a clear response of supplementing OM on $\mathrm{Zn}$ content in whole body that increase of OM dosage in diet resulted in an increase of $\mathrm{Zn}$ content in whole body. The effect was clearly shown when diet contained $2 \%$ and $4 \% \mathrm{OM}$.

Carapace Ca content tended to increase with increasing OM up to $2 \%$ in diet and further decreased at $4 \%$ inclusion rate (Table 7). Vannamei shrimp fed diet containing commercial diet (positive control) at $4 \%$ had a significant lower carapace Ca content compared to shrimp fed OM at level of $2 \%$, but did not differed from shrimp fed $\mathrm{OM}$ at $1 \%$ and $4 \%$. This might indicate that vannamei shrimp seemed efficiently utilize Ca from OM at moderate level. At highest level of 4\%, adverse effect of the mineral supplementing both in form of organic and inorganic caused lower Ca content in carapace. Many studies have reported the negative effects of high Ca supplementation on growth and mineral availability in aquatic animal. In case of tiger shrimp, maximum growth was found when diet contains no supplemental $\mathrm{Ca}$ and $0.5 \%$ supplemental P. Excess dietary Ca appears to have an inhibitory effect on the role of P as a nutrient (Penaflorida, 1999). Similar result was found in tiger puffer where diet contain no Ca supplement can maintain the normal growth if the diet contains $0.5 \%$ supplemental $P$ (Laining et al., 2011).

In contrast, dietary OM did not significantly affect phosphorus concentration in carapace. Similar to the whole body $\mathrm{Zn}$ content, there was also a linear trend of response dose of dietary OM on carapace $\mathrm{Zn}$ content. Dietary OM at all inclusion rates had a significant effect compared to positive control. The highest carapace $\mathrm{Zn}$ content was found in groups fed the highest inclusion level at $4 \%$ (OM4).

Even though most of the minerals such as $\mathrm{Ca}, \mathrm{P}$, $\mathrm{Mg}$, and $\mathrm{Zn}$ are more available to aquatic animal as inorganic form (Laining et al., 2012; Uyan et al., 2007), this trial confirmed that vannamei shrimp can also utilize element from organic mineral mixture in particular $\mathrm{Zn}$ even better than in form of inorganic material which is very common form in mineral mixture used for aquafeed.

Since the possible mechanism of the OM in stimulating the growth and survival rate is still not clearly in this present study, indepth analysis about the mineral content and other active coumpounds of the OM need to be done. This is necessary to clarify their roles on the growth, mineral utilization, and immune response on fish and other aquatic animals. 
Table 7. Concentration of Ca, P (\%), dan $\mathrm{Zn}$ in whole body and carapace of vannamei shrimp fed a graded levels of organic mineral $(n=2)$

\begin{tabular}{lcccc}
\hline \multirow{2}{*}{ Mineral content } & \multicolumn{4}{c}{ OM dosages } \\
\cline { 2 - 5 } & Positive control & OM1 & OM2 & OM4 \\
\hline Whole body mineral: & & & \\
Calcium (\%) & $2.74^{\mathrm{a}} \pm 0.71$ & $2.98^{\mathrm{a}} \pm 0.13$ & $2.63^{\mathrm{a}} \pm 0.21$ & $2.54^{\mathrm{a}} \pm 0.19$ \\
Phosphorus (\%) & $0.97^{\mathrm{a}} \pm 0.07$ & $0.99^{\mathrm{a}} \pm 0.01$ & $0.98^{\mathrm{a}} \pm 0.01$ & $0.80^{\mathrm{a}} \pm 0.23$ \\
Zinc (mg/kg) & $40.50^{\mathrm{a}} \pm 0.71$ & $49.00^{\mathrm{ab}} \pm 0.00$ & $51.00^{\mathrm{b}} \pm 4.20$ & $57.50^{\mathrm{b}} \pm 2.12$ \\
\hline Carapace mineral: & & & & \\
Calcium (\%) & $9.15^{\mathrm{a}} \pm 0.21$ & $10.00^{\mathrm{a}} \pm 0.57$ & $20.95^{\mathrm{b}} \pm 0.78$ & $8.10^{\mathrm{a}} \pm 1.13$ \\
Phosphorus (\%) & $0.96^{\mathrm{a}} \pm 0.1$ & $0.89^{\mathrm{a}} \pm 0.0$ & $0.88^{\mathrm{a}} \pm 0.1$ & $1.1^{\mathrm{a}} \pm 0.2$ \\
Zinc (mg/kg) & $17.1^{\mathrm{a}} \pm 2.4$ & $32.1^{\mathrm{b}} \pm 0.7$ & $43.2^{\mathrm{c}} \pm 3.3$ & $52.0^{\mathrm{c}} \pm 1.4$ \\
\hline
\end{tabular}

Note: Values are the mean \pm SD. The mean values with different superscript are significantly different $(\mathrm{P}<0.05)$

\section{CONCLUSION}

Based on growth, survival rate, and whole body and carapace $\mathrm{Zn}$ content, supplementation of $\mathrm{OM}$ at level of $1 \mathrm{~g} / 100 \mathrm{~g}$ diet can be used as replacement of mineral mixture for diet of vannamei shrimp. Inclusion of the OM up to $4 \mathrm{~g} / 100 \mathrm{~g}$ improved $\mathrm{Zn}$ utilization of the shrimp, but reduced the carapace Ca content of vannamei shrimp.

\section{ACKNOWLEDGEMENT}

The authors thank to CV Minatama, Lampung for providing organic mineral used in this experiment.

\section{REFERENCES}

AOAC International. (1999). Official methods of analysis. $16^{\text {th }}$ Edn. Association of Official Analytical Chemists International, Gaithersberg, Maryland. USA, 1141 pp.

Fodge, D., Rattanagulvaranon, S., \& Huong, T.M. (2011). Making strides in aquaculture with natural trace minerals. Aquaculture Asia Pacific, 7(3), 2425.

Folch, J., Lees, M., \& Sloanne-Stanley, G.H. (1957). A simple method for isolation and purification of total lipids from animal tissues. Journal of Biological Chemistry, 226, 497-509.

Laining, A., Ishikawa, M., Kyaw, K., Gao, J., Binh, N.T., Koshio, S., Yamaguchi, S., Yokoyama, S., \& Koyama, J. (2011). Dietary calcium/phosphorus ratio influences the efficacy of microbial phytase on growth, mineral digestibility and vertebral mineralization in juvenile tiger puffer, Takifugu rubripes. Aquaculture Nutrition, 17, 267-277.

Laining, A., Ishikawa, M., Koshio, S., Lideman, \& Yokoyama, S. (2012). Dietary inorganic phosphorus or microbial phytase supplementation im- proves growth, nutrient utilization and phosphorus mineralization of juvenile red sea bream, Pagrus major, fed soybean-based diets. Aquaculture Nutrition, 18, 502-511.

Laining, A., \& Kristanto, A.H. (2015). Aquafeed development and utilization of alternative dietary ingredients in aquaculture feed formulations in Indonesia. Proceeding on Regional Technical Consultation on Feeds. SEAFDEC. Iloilo, Phillipines (In Preparation). $20 \mathrm{pp}$.

Lall, S.P. (2002). The minerals. In Halver, J.E., \& Hardy, R.W. (Eds.), Fish Nutrition, $3^{\text {rd }}$ ed. Academic Press, San Diego. CA, p. 259-308.

Lin, Y.H., \& Shiau, S.Y. (2005). Dietary selenium requirements of juvenile grouper, Epinephelus malabaricus. Aquaculture, 250, 356-363.

Lorentzen, M., Maage, A., \& Julshamn, K. (1994)). Effects of dietary selenite or selenomethionine on tissue selenium levels of atlantic salmon (Salmo salar). Aquaculture, 121, 359-367.

Penaflorida, V.D. (1999). Interaction between dietary levels of calcium and phosphorus on growth of juvenile shrimp, Penaeus monodon. Aquaculture, 172, 281-289.

Rotruck, J.T., Pope, A.L., Ganther, H.E., Swanson, A.B., Hafeman, D.G., \& Hoekstra, W.G. (1973). Selenium: biochemical role as a component of glutathione peroxidase. Science, 179, 585-590.

Uyan, O., Koshio, S., Ishikawa, M., Uyan, S., Ren, T., Yokoyama, S., Komilus, C.F., \& Michael, F.R. (2007). Effects of dietary phosphorus and phospholipid level on growth, and phosphorus deficiency signs in juvenile Japanese flounder, Paralichthys olivaceus. Aquaculture, 267, 44-54.

Wang, C., \& Lovell, R.T. (1997). Organic selenium sources, selenomethionine and selenoyeast, have higher bioavailability than an inorganic selenium 
source, sodium selenite in diets for channel catfish (Ictalurus punctatus). Aquaculture, 152, 223-234.
Watanabe, T., Kiron, V., \& Satoh, S. (1997). Trace mineral in fish nutrition. Aquaculture, 151, 185-207. 